\title{
A social work study on detecting organizational and job related factors creating stress: A case study of hydro power employees
}

\author{
Gholamali Iravani $^{\mathrm{a}^{*}}$, Akbar Iravani ${ }^{\mathrm{b}}$, Ebrahim Jafari $^{\mathrm{c}}$, Samaneh Salimi ${ }^{\mathrm{d}}$ and Mohammad Reza $\operatorname{Iravani}^{\mathrm{e}}$
}

${ }^{a}$ Technical \& Scientific University, Iran

${ }^{b}$ Ministry of Education and Training, Iran

${ }^{c}$ Ministry of Advertisement, Iran

${ }^{d}$ Counselling Department, University of Esfahan, Esfahan, Iran

${ }^{e}$ Department of Social Work, Islamic Azad University of Khomeinishahr, Khomeinishahr Branch, Daneshjou Blvd, Iran

AR T I C L E I F O AB S T R C T

Article history:

Received December 15, 2011

Received in Revised form

February, 14, 2011

Accepted 24 March 2012

Available online

March 292012

Keywords:

Stress

Job satisfaction

Employee performance

Working conditions

\begin{abstract}
The study investigates different factors influencing people to have more stress in a hydropower unit located in city of Esfahan, Iran. Since there were only 81 people working for customer service section of this company and the proposed study tries to focus only on this part of the firm we have decided to distribute questionnaires among all of them. The questionnaire consists of two parts, in the first part; we gather all private information such as age, gender, education, job experience, etc. through seven important questions. In the second part of the survey, there are 66 questions, which include all the important factors influencing employees' stress. Cronbach alpha is calculated as 0.946 , which is well above the minimum acceptable level. The results of our ANOVA tests shows that among different factors, difficulty of working condition as well as work pressure are two most important factors increasing stress among employees. The other findings indicate that there is not a significant difference on work stress among different groups of employees in terms of their job title, educational level, employment type and gender $(\mathrm{P}>0.05)$. The other finding indicates that there is a meaningful difference between different groups of people with various ages, marital status and job experience $(\mathrm{P}>0.05)$.
\end{abstract}

\section{Introduction}

Stress solely can have harmful influences on working conditions and in many cases; people may leave work place solely because of the existence of stress in working environment. Stress may be created by many factors such as competition, work pressure, etc. Understanding the nature and root of stress in organizations helps management teams remove most important ones and reduce the impact of all factors by providing different alternatives (Çekmecelioğlu \& Günsel, 2011). During the past few decades, there have been tremendous efforts on learning how it is possible to reduce stress among employees (Bassett et al., 1987; Law et al., 1995).

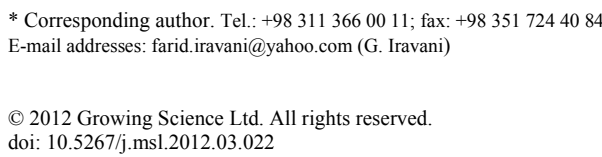


Gupta and Beehr (1979) are believed the first people who investigated the relationship between job stress and employee behaviors. They studied the relationship between four job stresses including role ambiguity, underutilization of skills, role overload and resource inadequacy and two employee withdrawal behaviors including absenteeism and turnover. They also investigated joint prediction of employee withdrawal because of job stress and some selected background characteristics. They collected the necessary information from 651 employees in five different firms through personal interviews and company records. Their analysis revealed that job stress was associated with employee withdrawal behaviors. They also concluded that prediction of subsequent behaviors was stronger than prediction of prior behaviors, and explained that the predictive power of job stress and background variables taken together was, at least, as powerful as the predictive power of background variables alone.

Smith et al. (1992) examined critical job design elements, which could impact worker stress responses in an electronic monitoring context. A questionnaire survey of employees in telecommunications companies representative of each region in the United States surveyed job stress in directory assistance, service representative and clerical jobs with specific emphasis on the influence of electronic monitoring of job performance, satisfaction and employee health. The results indicated that employees who had their performance electronically monitored perceived their working conditions as more stressful, and reported higher levels of job boredom, psychological tension, anxiety, depression, anger, health complaints and fatigue.

Slate and Vogel (1997) performed another study on the perceived atmosphere for participation in correctional decision making and its impact on employee stress and thoughts about quitting. The study concentrated on the perceptions of correctional officers influencing their participation in decision-making and the relationship between physical stress, organizational stress and thoughts about leaving the job. The survey was performed among 486 employees from seven correctional institutions in the Southeast United States. The results of the implementation of structural model revealed that showed that as employee participation increased, physical and occupational stress decreased. Thoughts about quitting were related to higher levels of occupational stress, physical stress and the perception of a negative atmosphere for participation.

de Ruyter et al. (2001) investigated the role of stress in call centers in terms of performance or job satisfaction. They surveyed which forms of leadership styles and empowerment decrease role stress and how this subsequently influences job satisfaction, performance, organizational commitment and turnover intentions. They reported that specifically the autonomy dimension of empowerment had a role-stress-reducing impact. Interesting substantive direct positive impacts of empowerment competence and leadership consideration on job satisfaction were also considered. Job satisfaction was found to be conducive to job performance. Besides, the study revealed that job satisfaction could reduce turnover intentions, directly or indirectly via organizational commitment.

Vearing and Mak (2007) performed an empirical investigation on the joint impacts of the big five personality factors and an extended model of work stress based on study on effort-reward imbalance (ERI), on employees' depressive symptoms. They reported an association between neuroticism (N) and OVC. Regression analysis of depressive symptoms disclosed a medium influence of $\mathrm{N}$, followed by small effects of workplace social support, conscientiousness (C), and ERI ratio, accounting for $44 \%$ of the variance in depressive symptoms.

Kim et al. (2009) investigated the moderating roles of organization level and gender in the relationship between job satisfaction and role stress for hotel employees. The study includes measures of job satisfaction, role stress in terms of both conflict and ambiguity and demographic data was implemented to collect information from hotel employees in Republic of Korea. The results indicated that the impact of role stress on job satisfaction is substantially stronger for female employees and supervisory employees than male and non-supervisory workers. 
Saastamoinen et al. (2009) examined the own and independent associations of job strain, workplace bullying, organizational justice and work-home interface with pain. Among women, all psychosocial factors were related to both acute and chronic pain when adjusted for confounders only. Among men, when adjusted for confounders only, all psychosocial factors were associated with acute and chronic pain, except for family-to-work conflicts among those with acute pain.

Chiang et al. (2010) studied the moderating impacts of job control and work-life balance practices on employee stress in the hotel and catering industry. The results of this survey explained that high job demands coupled with low job control and the availability of work-life balance practices leads in a higher level of stress.

Tabatabaei et al. (2011) studied the general health, stress associated to the work and job satisfaction of the Hormozgan Cement Factory employees. The study was semi-experimental with the pre-test and post-test without control group and to improve mental health of employees, psychological trainings and motivational models were executed. The results demonstrated that general health and job satisfaction of employees were higher than average $(\alpha=0.01)$ but their job stress was lower than average $(\alpha=0.01)$. After intervention, results disclosed improvement of job stress and such trainings and models recommended for improvement of employees stress.

Coelho et al. (2011) studied the mediating impacts of role stress and intrinsic motivation using contextual factors and the creativity of frontline employees. They reported that the creativity of frontline service employees is associated positively with role conflict and negatively with role ambiguity.

The present study investigates to find out the important factors influencing job stress in one of Iranian hydro facilities. The structure of this study first explains characteristics of all people who participated in our survey.

\section{The proposed study}

The study investigates different factors influencing people to have more stress in a hydropower unit located in city of Esfahan, Iran. Since there were only 81 people working for customer service section of this company and the proposed study tries to focus only on this part of the firm we have decided to distribute questionnaires among all of them. The questionnaire consists of two parts, in the first part, we gather all private information such as age, gender, education, job experience, etc. through seven important questions. In the second part of the survey, there are 52 questions, which include all the important factors influencing employees' stress.

\subsection{Personal characteristics of surveyed people}

As we explained, there are 81 people participated in our survey. In terms of their gender, there were 73 male and 8 female so approximately $90 \%$ of the surveyed people are from man. In terms of their educational background, 10 people had only 9 years of educational background, 48 people finished high school and 23 people had colleague education. While 15 people were single, 66 people were married. In terms of employment type, 21 people were permanent employee, 11 people maintained a five-year contract, 44 people had one-year contract and only 5 employee were on temporary contract. In terms of job experience, 20 people aged between 20-29, 36 people aged between 30-39, 15 people were between 40 to 49 and finally, 10 employees were over 50 years of age. In terms of job experience, 45 people has from one to ten years of job experience, 15 people had between 11 to 20 years of job experiences and 21 people has between 21 to 30 years of job experience. Finally, 23 people were regular employee, 14 were workers, 30 people were working in customer service and 14 people were hired as accountants. 


\subsection{Questionnaire}

Table 1 shows details of all questions associated with the proposed study of this paper.

Table 1

Details of survey

\begin{tabular}{|c|c|c|c|c|}
\hline Q & Title & Mean & Std. dev & Std. Err. \\
\hline 1 & The feeling that payment does not cover my expenses. & 3.84 & 1.156 & 0.128 \\
\hline 2 & Firm does not pay enough attention to employee's accommodation. & 4.28 & 1.186 & 0.132 \\
\hline 3 & Firm does not pay enough attention to employee's transportation. & 3.12 & 1.426 & 0.158 \\
\hline 4 & There are significant noises in the organization. & 3.57 & 1.369 & 0.152 \\
\hline 5 & Management does not care about job experience. & 3.65 & 1.485 & 0.165 \\
\hline 6 & There are not sufficient equipments. & 3.15 & 1.236 & 0.137 \\
\hline 7 & The employees are not sufficient to be responsive to customers. & 3.22 & 1.423 & 0.158 \\
\hline 8 & Temperature is not properly adjusted. & 2.88 & 1.298 & 0.144 \\
\hline 9 & There is not sufficient visibility. & 2.53 & 1.314 & 0.146 \\
\hline 10 & There is a significant amount of work to do. & 3.80 & 1.317 & 0.146 \\
\hline 11 & There are not supportive entertainment programs. & 3.99 & 1.220 & 0.136 \\
\hline 12 & There is not enough respect towards employees. & 3.75 & 1.318 & 0.146 \\
\hline 13 & There is fear that people may lose their jobs. & 3.65 & 1.550 & 0.172 \\
\hline 14 & There are too much expectations from the workers. & 3.09 & 1.343 & 0.149 \\
\hline 15 & The customers are mostly aggressive. & 3.21 & 1.252 & 0.139 \\
\hline 16 & There is no support for hard working conditions. & 3.22 & 1.508 & 0.168 \\
\hline 17 & There are discriminations among people with various types of employment. & 4.05 & 1.350 & 0.150 \\
\hline 18 & There are discriminations among people with various types of job experiences. & 3.47 & 1.361 & 0.151 \\
\hline 19 & The feeling that employee must always be a good voice of customer. & 2.10 & 1.168 & 0.130 \\
\hline 20 & Special circumstances of work place. & 2.51 & 1.484 & 0.165 \\
\hline 21 & There is not over pay for overtime work. & 3.32 & 1.540 & 0.171 \\
\hline 22 & There is not enough time to finish all works on time. & 3.16 & 1.373 & 0.153 \\
\hline 23 & Displacement of employees happens without asking the opinions of employees. & 3.21 & 1.618 & 0.180 \\
\hline 24 & Management always looks for shortcoming and do not pay to other issues. & 3.69 & 1.190 & 0.132 \\
\hline 25 & There are not enough hardware and software packages. & 3.26 & 1.340 & 0.149 \\
\hline 26 & The people with more job experience work less. & 3.19 & 1.476 & 0.164 \\
\hline 27 & The people with less job experience work less. & 2.77 & 1.425 & 0.158 \\
\hline 28 & The employees are not participated in decision-making procedures. & 2.89 & 1.396 & 0.155 \\
\hline 29 & Promotion policy is not good. & 3.09 & 1.606 & 0.178 \\
\hline 30 & There is no trust among employees. & 2.94 & 1.363 & 0.151 \\
\hline 31 & Connections work better than regulations. & 3.48 & 1.333 & 0.148 \\
\hline 32 & Customers' complaints play important role. & 2.95 & 1.254 & 0.139 \\
\hline 33 & Work duties are not clear for employees. & 3.21 & 1.429 & 0.159 \\
\hline 34 & The management is making their decision selectively. & 2.88 & 1.354 & 0.150 \\
\hline 35 & Limited number of employees performs a significant amount of work. & 3.38 & 1.480 & 0.164 \\
\hline 36 & It is not possible to go to vacations. & 3.16 & 1.529 & 0.170 \\
\hline 37 & Management does not care about employees' living and personal affairs. & 3.86 & 1.181 & 0.131 \\
\hline 38 & The loans are sufficient. & 4.05 & 1.331 & 0.148 \\
\hline 39 & There is poor management system. & 3.41 & 1.358 & 0.151 \\
\hline 40 & All other problems are transferred to customers. & 3.46 & 1.423 & 0.158 \\
\hline 41 & The rules and regulations have some flaws. & 3.20 & 1.336 & 0.148 \\
\hline 42 & There is no promotion or punishment plan. & 3.54 & 1.314 & 0.146 \\
\hline 43 & The working condition is boring. & 2.93 & 1.498 & 0.166 \\
\hline 44 & Overtime work is insufficient. & 3.69 & 1.402 & 0.156 \\
\hline 45 & The feedbacks from experienced people are not used. & 3.30 & 1.327 & 0.147 \\
\hline 46 & There are extra job replacements. & 2.49 & 1.574 & 0.175 \\
\hline 47 & There are just too much expectations from top management. & 3.07 & 1.253 & 0.139 \\
\hline 48 & Employees are not sufficiently aware of the rules and regulations. & 2.94 & 1.258 & 0.140 \\
\hline 49 & There are just too much attentions on degrees instead of experiences. & 3.42 & 1.350 & 0.150 \\
\hline 50 & There is just too much discrimination among employees. & 3.44 & 1.405 & 0.156 \\
\hline 51 & Stresses are transferred from other sections to employees. & 3.35 & 1.459 & 0.169 \\
\hline 52 & There is just too much attention to customer care. & 3.35 & 1.429 & 0.162 \\
\hline 53 & There is fear on making mistake due to high volume of work. & 3.14 & 1.262 & 0.140 \\
\hline 54 & There are several issues associated with rate of charges. & 2.52 & 1.256 & 0.140 \\
\hline 55 & There are eavesdropping among some employees. & 3.38 & 1.578 & 0.175 \\
\hline 56 & Employees cannot use their vocational events due to high volume work. & 3.73 & 1.225 & 0.136 \\
\hline 57 & There are just too much unreachable deadlines. & 3.62 & 1.225 & 0.136 \\
\hline 58 & Employees are not feeling good for outsourcing activities. & 3.77 & 1.519 & 0.169 \\
\hline 59 & The works are not performed properly. & 3.46 & 1.285 & 0.143 \\
\hline 60 & Employees are asked to perform works while they are qualified for. & 3.54 & 1.215 & 0.135 \\
\hline 61 & Works are not assigned fairly among employees. & 3.77 & 1.186 & 0.132 \\
\hline 62 & There is no justice for giving awards. & 4.15 & 1.236 & 0.137 \\
\hline 63 & There is no replacement for employees when some go on vacation. & 3.58 & 1.386 & 0.154 \\
\hline 64 & There is no friendship relationship among employees. & 2.72 & 1.316 & 0.146 \\
\hline 65 & There is feedback for customers' complaints. & 2.73 & 1.265 & 0.141 \\
\hline 66 & Customers are not aware of rates and regulations. & 3.28 & 1.630 & 0.181 \\
\hline
\end{tabular}


As we can observe from the results of Table 1, the mean of responses were varied from 2.10 to 4.28 . Table 2 shows details of our analysis for descriptive questions.

Table 2

Descriptive questions

\begin{tabular}{llccc}
\hline Q & Title & Mean & Std. dev & Std. Err. \\
\hline 1 & Pressure between management and employee & 3.183 & 0.819 & 0.091 \\
2 & Job conditions and difficulties & 3.472 & 0.877 & 0.097 \\
3 & Unsuitable work conditions & 3.098 & 1.102 & 0.122 \\
4 & The fear from working conditions & 3.345 & 0.890 & 0.098 \\
5 & Summary & 3.374 & 0.729 & 0.081 \\
\hline
\end{tabular}

\section{Results}

In this section, we present details of our statistical tests on the questionnaire of this survey. We have performed ANOVA test to examine the impact of different factors such as groups of jobs, ages, etc. on influencing stress among employees.

\subsection{The impact of stress on different groups of jobs}

Table 3 shows details of our ANOVA test to study the impact of stress among different groups of jobs.

\section{Table 3}

The results of ANOVA test on difference between various groups of jobs

\begin{tabular}{|c|c|c|c|c|c|c|}
\hline & Source of change & Sum of Squares & $\mathrm{df}$ & Mean of squares & $\mathrm{F}$ & P-value \\
\hline \multirow{3}{*}{$\begin{array}{l}\text { Pressure between } \\
\text { management and } \\
\text { employee }\end{array}$} & Between groups & 3.590 & 3 & 1.197 & & \\
\hline & Inside group & 44.576 & 78 & 0.686 & 1.745 & 0.167 \\
\hline & Total & 48.167 & 81 & - & & \\
\hline \multirow{3}{*}{$\begin{array}{l}\text { Job conditions and } \\
\text { difficulties }\end{array}$} & Between groups & 3.422 & 3 & 1.141 & & \\
\hline & Inside group & 50.03 & 78 & 0.770 & 1.482 & 0.228 \\
\hline & Total & 53.452 & 81 & - & & \\
\hline \multirow{3}{*}{$\begin{array}{l}\text { Unsuitable work } \\
\text { conditions }\end{array}$} & Between groups & 6.950 & 3 & 2.317 & & \\
\hline & Inside group & 73.420 & 78 & 1.130 & 2.051 & 0.115 \\
\hline & Total & 80.370 & 81 & - & & \\
\hline \multirow{3}{*}{$\begin{array}{l}\text { The fear from } \\
\text { working conditions }\end{array}$} & Between groups & 2.725 & 3 & 0.908 & & \\
\hline & Inside group & 51.744 & 78 & 0.796 & 1.141 & 0.339 \\
\hline & Total & 54.468 & 81 & - & & \\
\hline \multirow[t]{3}{*}{ Total } & Between groups & 3.909 & 3 & 1.303 & & \\
\hline & Inside group & 33.012 & 78 & 0.508 & 2.566 & 0.062 \\
\hline & Total & 36.921 & 81 & - & & \\
\hline
\end{tabular}

As we can observe from the results of Table 3, there is no meaningful relationship between each group. Therefore, we can conclude that stress is not any different among various groups of jobs.

\subsection{The impact of stress on different groups of ages}

The second question of our survey to know whether there is any relationship between stresses in different groups of ages. Table 4 shows details of our ANOVA test to study the impact of stress among different groups of ages. As we can observe from the results of Table 4, there is meaningful relationship on having pressure between management and employee $(\mathrm{P}>0.05)$, the fear from working conditions. However, there is no meaningful relationship on job conditions and difficulties, unsuitable work condition. In summary, we can conclude that stress has some influences among various groups of ages. 


\section{Table 4}

The results of ANOVA test on difference between various groups of ages

\begin{tabular}{|c|c|c|c|c|c|c|}
\hline & Source of change & Sum of Squares & $\mathrm{df}$ & Mean of squares & $\mathrm{F}$ & $\mathrm{P}$-value \\
\hline \multirow{3}{*}{$\begin{array}{l}\text { Pressure between } \\
\text { management and } \\
\text { employee }\end{array}$} & Between groups & 4.035 & 3 & 1.345 & 2.321 & \\
\hline & Inside group & 42.314 & 73 & 0.580 & & 0.042 \\
\hline & Total & 46.349 & 76 & & & \\
\hline \multirow{3}{*}{$\begin{array}{l}\text { Job conditions and } \\
\text { difficulties }\end{array}$} & Between groups & 1.642 & 3 & $0 . \overline{547}$ & $0 . \overline{776}$ & $\overline{0.511}$ \\
\hline & Inside group & 51.498 & 73 & 0.705 & & . \\
\hline & Total & 53.140 & 76 & & & \\
\hline \multirow{3}{*}{$\begin{array}{l}\text { Unsuitable work } \\
\text { conditions }\end{array}$} & Between groups & 1.798 & 3 & $0 . \overline{599}$ & $0 . \overline{514}$ & $0 . \overline{674}$ \\
\hline & Inside group & 85.066 & 73 & 1.165 & & \\
\hline & Total & 86.864 & 76 & & & \\
\hline \multirow{3}{*}{$\begin{array}{l}\text { The fear from } \\
\text { working conditions }\end{array}$} & Between groups & 9.172 & 3 & $3 . \overline{057}$ & $\overline{4.515}$ & $\overline{0.06}$ \\
\hline & Inside group & 49.430 & 73 & 0.677 & & \\
\hline & Total & 58.602 & 76 & & & \\
\hline \multirow[t]{3}{*}{ Total } & Between groups & 2.428 & 3 & $0 . \overline{809}$ & $2 . \overline{780}$ & $0 . \overline{049}$ \\
\hline & Inside group & 33.191 & 73 & 0.455 & & \\
\hline & Total & 35.619 & 76 & & & \\
\hline
\end{tabular}

\subsection{The impact of stress on different groups with various educational backgrounds}

The third question of our survey is to know whether there is any relationship between stresses in different educational groups. Table 5 shows details of our ANOVA test to study the impact of stress among people with various educational backgrounds.

\section{Table 5}

The results of ANOVA test between various groups with different educational backgrounds

\begin{tabular}{|c|c|c|c|c|c|c|}
\hline & Source of change & Sum of Squares & $\mathrm{df}$ & Mean of squares & $\mathrm{F}$ & P-value \\
\hline \multirow{3}{*}{$\begin{array}{l}\text { Pressure between } \\
\text { management and } \\
\text { employee }\end{array}$} & Between groups & 0.195 & 2 & 0.097 & 0.148 & 0.863 \\
\hline & Inside group & 49.449 & 75 & 0.659 & & \\
\hline & Total & 49.644 & 77 & & & \\
\hline \multirow{3}{*}{$\begin{array}{l}\text { Job conditions and } \\
\text { difficulties }\end{array}$} & Between groups & 0.689 & 2 & $0 . \overline{345}$ & $0 . \overline{444}$ & $0 . \overline{643}$ \\
\hline & Inside group & 58.139 & 75 & 0.775 & & \\
\hline & Total & 58.828 & 77 & & & \\
\hline \multirow{3}{*}{$\begin{array}{l}\text { Unsuitable work } \\
\text { conditions }\end{array}$} & Between groups & 3.214 & 2 & $1 . \overline{607}$ & $1 . \overline{376}$ & $0 . \overline{259}$ \\
\hline & Inside group & 87.610 & 75 & 1.168 & & \\
\hline & Total & 90.824 & 77 & & & \\
\hline \multirow{3}{*}{$\begin{array}{l}\text { The fear from } \\
\text { working conditions }\end{array}$} & Between groups & 3.796 & 2 & 1.898 & 2.538 & 0.086 \\
\hline & Inside group & 56.088 & 75 & 0.748 & & \\
\hline & Total & 59.884 & 77 & & & \\
\hline \multirow[t]{3}{*}{ Total } & Between groups & 1.068 & 2 & $0 . \overline{534}$ & 1.059 & $0 . \overline{352}$ \\
\hline & Inside group & 37.816 & 75 & 0.504 & & \\
\hline & Total & 38.883 & 77 & & & \\
\hline
\end{tabular}

As we can observe from the results of Table 5, there is no meaningful relationship between each group $(\mathrm{P}>0.05)$. Therefore, we can conclude that stress is not any different among various groups with various educational backgrounds.

\subsection{The impact of stress on different groups with various employment statuses}

The fourth question of our survey is to know whether there is any relationship between stresses in various educational groups. Table 6 shows details of our ANOVA test to study the impact of stress among people with various employment statues. As we can observe from the results of Table 6 , there is no meaningful relationship between each group $(\mathrm{P}>0.05)$. Therefore, we can conclude that stress is not any different among various groups with various employment statues. 
Table 6

The results of ANOVA test between various groups with different employment statues

\begin{tabular}{|c|c|c|c|c|c|c|}
\hline & Source of change & Sum of Squares & $\mathrm{df}$ & Mean of squares & $\mathrm{F}$ & P-value \\
\hline \multirow{3}{*}{$\begin{array}{l}\text { Pressure between } \\
\text { management and } \\
\text { employee }\end{array}$} & Between groups & 0.636 & 3 & 0.212 & 0.336 & 0.799 \\
\hline & Inside group & 45.424 & 72 & 0.631 & & \\
\hline & Total & 46.060 & 75 & & & \\
\hline \multirow{3}{*}{$\begin{array}{l}\text { Job conditions and } \\
\text { difficulties }\end{array}$} & Between groups & 0.638 & 3 & $0 . \overline{213}$ & $0 . \overline{310}$ & $0 . \overline{818}$ \\
\hline & Inside group & 49.320 & 72 & 0.658 & & \\
\hline & Total & 49.958 & 75 & & & \\
\hline \multirow{3}{*}{$\begin{array}{l}\text { Unsuitable work } \\
\text { conditions }\end{array}$} & Between groups & 1.396 & 3 & $0 . \overline{465}$ & $0 . \overline{390}$ & $0 . \overline{760}$ \\
\hline & Inside group & 85.772 & 72 & 1.191 & & \\
\hline & Total & 87.168 & 75 & & & \\
\hline \multirow{3}{*}{$\begin{array}{l}\text { The fear from } \\
\text { working conditions }\end{array}$} & Between groups & 1.263 & 3 & $0 . \overline{421}$ & 0.542 & $0 . \overline{655}$ \\
\hline & Inside group & 55.900 & 72 & 0.766 & & \\
\hline & Total & 57.163 & 75 & & & \\
\hline \multirow[t]{3}{*}{ Total } & Between groups & 0.119 & 3 & 0.040 & $0 . \overline{083}$ & 0.969 \\
\hline & Inside group & 34.311 & 72 & 0.477 & & \\
\hline & Total & 34.430 & 75 & & & \\
\hline
\end{tabular}

\subsection{The impact of stress on different groups with various working experiences}

The fifth question of our survey is to know whether there is any relationship between stresses in various working experiences. Table 7 shows details of our ANOVA test to study the impact of stress among people with various job experiences.

Table 7

The results of ANOVA test between various groups with different job experiences

\begin{tabular}{|c|c|c|c|c|c|c|}
\hline & Source of change & Sum of Squares & $\mathrm{df}$ & Mean of squares & $\mathrm{F}$ & P-value \\
\hline \multirow{3}{*}{$\begin{array}{l}\text { Pressure between } \\
\text { management and } \\
\text { employee }\end{array}$} & Between groups & 0.636 & 3 & 0.212 & 0.336 & 0.799 \\
\hline & Inside group & 45.424 & 72 & 0.631 & & \\
\hline & Total & 46.060 & 75 & & & \\
\hline \multirow{3}{*}{$\begin{array}{l}\text { Job conditions and } \\
\text { difficulties }\end{array}$} & Between groups & 0.638 & 3 & 0.213 & 0.310 & 0.818 \\
\hline & Inside group & 49.320 & 72 & 0.658 & & \\
\hline & Total & 49.958 & 75 & & & \\
\hline \multirow{3}{*}{$\begin{array}{l}\text { Unsuitable work } \\
\text { conditions }\end{array}$} & Between groups & 1.396 & 3 & 0.465 & 0.390 & 0.760 \\
\hline & Inside group & 85.772 & 72 & 1.191 & & \\
\hline & Total & 87.168 & 75 & & & \\
\hline \multirow{3}{*}{$\begin{array}{l}\text { The fear from } \\
\text { working conditions }\end{array}$} & Between groups & 1.263 & 3 & $0 . \overline{421}$ & 0.542 & 0.655 \\
\hline & Inside group & 55.900 & 72 & 0.766 & & \\
\hline & Total & 57.163 & 75 & & & \\
\hline \multirow[t]{3}{*}{ Total } & Between groups & 0.119 & 3 & 0.040 & 0.083 & 0.969 \\
\hline & Inside group & 34.311 & 72 & 0.477 & & \\
\hline & Total & 34.430 & 75 & & & \\
\hline
\end{tabular}

As we can observe from the results of Table 6, there is no meaningful relationship between each group $(\mathrm{P}>0.05)$. Therefore, we can conclude that stress is not any different among various groups with various job experiences.

\subsection{The impact of stress on different groups with different genders}

The sixth question of our survey is to know whether there is any relationship between stresses in people with different genders. Bases on the results we obtained, we can conclude that gender does not play important role on creating stress among people. 


\section{Conclusion}

In this paper, we have presented an empirical study to investigate different factors influencing people to have more stress in a hydropower unit located in city of Esfahan, Iran. Since there were only 81 people working for customer service section of this company and the proposed study tries to focus only on this part of the firm we have decided to distribute questionnaires among all of them. The results of our ANOVA tests have shown that among different factors, difficulty of working condition as well as work pressure are two most important factors increasing stress among employees. The other findings indicate that there was not a significant difference on work stress among different groups of employees in terms of their job title, educational level, employment type and gender $(\mathrm{P}>0.05)$. The other finding indicates that there was a meaningful difference between different groups of people with various ages, marital status and job experience $(\mathrm{P}>0.05)$.

\section{Acknowledgment}

The authors would like to thank the officials of hydropower who helped us finish this work, completely.

\section{References}

Bassett, J.R., Marshall, P.M., \& Spillane, R. (1987). The physiological measurement of acute stress (public speaking) in bank employees. International Journal of Psychophysiology, 5(4), 265-273

Chiang, F.F.T., Birtch, T.A., \& Kwong Kwan, H. (2010). The moderating roles of job control and work-life balance practices on employee stress in the hotel and catering industry. International Journal of Hospitality Management, 29(1), 25-32.

Coelho, F., Augusto, M., \& Lages, L.F. (2011). Contextual factors and the creativity of frontline employees: The mediating effects of role stress and intrinsic motivation. Journal of Retailing, 87(1), 31-45.

Çekmecelioğlu, H.G., \& Günsel, A. (2011). Promoting creativity among employees of mature industries: The Effects Of Autonomy And Role Stress On Creative Behaviors And Job Performance. Procedia - Social and Behavioral Sciences, 24, 889-895.

de Ruyter, k., Wetzels, M., \& Feinberg, R. (2001). Role stress in call centers: Its effects on employee performance and satisfaction. Journal of Interactive Marketing, 15(2), 23-35.

Gupta, N., \& Beehr, T.A. (1979). Job stress and employee behaviors. Organizational Behavior and Human Performance, 23(3), 373-387.

Kim, B.P., Murrmann, S.K., \& Lee, G. (2009). Moderating effects of gender and organizational level between role stress and job satisfaction among hotel employees. International Journal of Hospitality Management, 28(4), 612-619.

Law, J., Pearce, P.L., \& Woods, B.A. (1995). Stress and coping in tourist attraction employees. Tourism Management, 16(4), 277-284.

Slate, R.N., \& Vogel, R.E. (1997). Participative management and correctional personnel: A study of the perceived atmosphere for participation in correctional decision making and its impact on employee stress and thoughts about quitting. Journal of Criminal Justice, 25(5), 397-408.

Smith, M.J., Carayon, P., Sanders, K.J., Lim, S-Y., \& LeGrande, D. (1992). Employee stress and health complaints in jobs with and without electronic performance monitoring. Applied Ergonomics, 23(1), 17-27.

Saastamoinen, P., Laaksonen, M., Leino-Arjas, P., \& Lahelma, E. (2009). Psychosocial risk factors of pain among employees. European Journal of Pain, 13(1), 102-108.

Tabatabaei, S., Hosseinian, S., \& Gharanjiki, B. (2011). General Health, Stress Associated to the Work and Job Satisfaction of Hormozgan Cement Factory Employees in Iran. Procedia - Social and Behavioral Sciences, 30, 1897-1901.

Vearing, A., \& Mak, A. S. (2007). Big five personality and effort-reward imbalance factors in employees' depressive symptoms. Personality and Individual Differences, 43(7), 1744-1755. 